\title{
Basin-scale changes of total organic carbon profiles in the eastern South Atlantic*
}

\author{
X.A. ÁLVAREZ-SALGADO, FÍZ F. PÉREZ, A.F. RÍOS and M.D. DOVAL \\ CSIC, Instituto de Investigacións Mariñas, Eduardo Cabello, 6. E-36208 Vigo. Spain. E-mail: xsalgado@iim.csic.es
}

\begin{abstract}
SUMMARY: Total organic carbon (TOC) samples were collected at 6 stations spaced $\sim 800 \mathrm{~km}$ apart in the eastern South Atlantic, from the Equator to $45^{\circ} \mathrm{S}$ along $9^{\circ} \mathrm{W}$. Analyses were performed by high temperature catalytic oxidation (HTCO) in the base laboratory. Despite the complex advection and mixing patterns of North Atlantic and Antarctic waters with

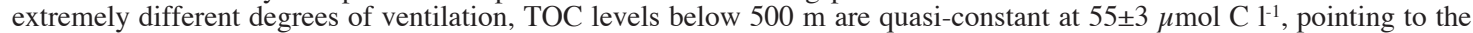
refractory nature of deep-water TOC. On the other hand, a TOC excess from 25 to $38 \mathrm{~g} \mathrm{C} \mathrm{m}^{-2}$ is observed in the upper 100 $\mathrm{m}$ of the permanently stratified nutrient-depleted Equatorial, Subequatorial and Subtropical upper ocean, where vertical turbulent diffusion is largely prevented. Conversely, TOC levels in the nutrient-rich upper layer of the Subantarctic Front only exceeds $9 \mathrm{~g} \mathrm{C} \mathrm{m}^{-2}$ the deep-water baseline. As much as $70 \%$ of the TOC variability in the upper $500 \mathrm{~m}$ is due to simple mixing of reactive TOC formed in the surface layer and refractory TOC in deep ocean waters, with a minor contribution (13\%) to oxygen consumption in the prominent subsurface AOU maximum at 200-400 m depth.
\end{abstract}

Key words: Dissolved Organic Carbon (DOC), Apparent Oxygen Utilisation (AOU), stratification, mixing, water masses, SE Atlantic Ocean.

\section{INTRODUCTION}

The key contribution of dissolved organic matter (DOM) to carbon cycling and the implications for the role of the oceans in the regulation of the anthropogenic $\mathrm{CO}_{2}$ excess have been issues of renewed interest during the last decade (Toggweiler, 1989; Bascatow and Maier-Reimer, 1991; Sambrotto et al., 1993; Legendre and Le Fèvre, 1995). An excess of degradable DOM in surface ocean waters - generated in situ by biological processes (Kirchman et al., 1993; Thingstad et al., 1997) - is a commonly observed world-wide trend (Copin-Montégut and Avril, 1993; Carlson et al., 1994; Pakulski and Benner, 1994; Chen et al., 1996). This DOM excess

\footnotetext{
*Received January 31, 2000. Accepted July 17, 2000
}

seems to be composed of a minor fraction of fastcycling, highly-labile material (Carlson and Ducklow, 1995), which constitutes the substrate for the microbial loop organisms (Azam et al., 1983; Kirchman et al., 1991). The major component of the observed excess appears to be phytogenic semilabile material, either directly released or resulting from photochemical transformation of labile molecules into less reactive compounds. A reduction in the bioavailability of surface water DOM after exposure to natural UV radiation levels has recently been demonstrated, and is probably due to photomineralisation of bioavailable DOM and the phototransformation of DOM to biorefractory substrates (Benner and Biddanda, 1998; Obernosterer et al., 1999). Conversely, accumulation of labile DOM in surface ocean waters could take place as a result of low 
growth and biomass of bacteria, caused by competition with phytoplankton for nutrients and predation respectively (Thingstad et al., 1997) or photochemical inhibition of bacterial ectoenzymes (Herndl et al., 1993). In areas where convective mixing follows summer stratification, accumulated DOM is locally exported downwards during winter mixing and contributes to the in situ oxygen consumption in subsurface waters (Copin-Montégut and Avril, 1993; Carlson et al., 1994). Alternatively, horizontal transport to areas where the DOM excess can be recycled (Hansell and Waterhouse, 1997) or where winter mixing occurs could be the final fate of the DOM produced in vast regions of the open ocean (Legendre and Le Fèvre, 1995). Therefore, Eppley and Peterson's (1979) concept of 'new production' needs to be revised because of the major contribution of DOM to organic carbon export, either vertically or horizontally (Bronk et al., 1994; Peltzer and Hayward, 1996). Regarding deep ocean waters, although some authors had suggested a contribution of DOM to oxygen consumption (Sugimura and Suzuki, 1988), the earlier statement that it is very old (4-6 $\mathrm{Kyr}$ ) and resistant to degradation is currently accepted (Williams and Druffell, 1987, Bauer et al., 1992). However, Hansell and Carlson (1998) have demonstrated that 'refractory' is not synonymous with 'eternal': DOM in deep ocean waters decreases by $30 \%$ from the recently formed deep waters of the North Atlantic ( $48 \mu \mathrm{mol} \mathrm{C}^{-1}$ ) to the $2 \mathrm{Kyr}$ older deep waters of the North Pacific (34 $\left.\mu \mathrm{mol} \mathrm{C} \mathrm{l}^{-1}\right)$.

There are several recent studies on the spatial and seasonal variability of dissolved organic carbon (DOC) at local scales (ca. $10^{1-2} \mathrm{~km} ;$ e.g. Copin-Montégut and Avril, 1993; Carlson et al., 1994; Chen et al., 1996; Peltzer and Hayward, 1996), but there is a lack of studies covering the basin scale ( $\mathrm{ca} 10^{3-4}$ $\mathrm{km})$, apart from the recent works by Hansell and Waterhouse (1997) and Doval and Hansell (2000) in the Indian and Pacific Oceans. The present work reports a limited number of DOC measurements in surface, thermocline and deep ocean waters in the $5500 \mathrm{~km}$ long WOCE (World Ocean Circulation Experiment) line A14, in the eastern South Atlantic.

The South Atlantic connects the northern sources of North Atlantic Deep Water (NADW) with the Antarctic, Pacific and Indian Oceans and allows the Intermediate (AAIW), Circumpolar (CDW) and Bottom (AABW) waters of Antarctic origin to penetrate the North Atlantic (Reid, 1989). Complex mixing of these water masses flowing opposite at different levels occurs (Peterson and Whitworth,
1989). In the upper ocean, the climatologically driven circulation (Fig. 1) imposes several contrasting zones, with crucial implications for carbon biogeochemistry. From north to south, A14 started in the Equatorial upwelling. Then, the section crossed the cyclonic Subequatorial gyre, up to the South Equatorial Current (SEC). Further south, the section enters the anticyclonic Subtropical gyre, a vast oligotrophic area. Finally, after the Subtropical Front, the section entered the Subantarctic zone and finished at the northern end of the Subantarctic Front (Peterson and Stramma, 1991).

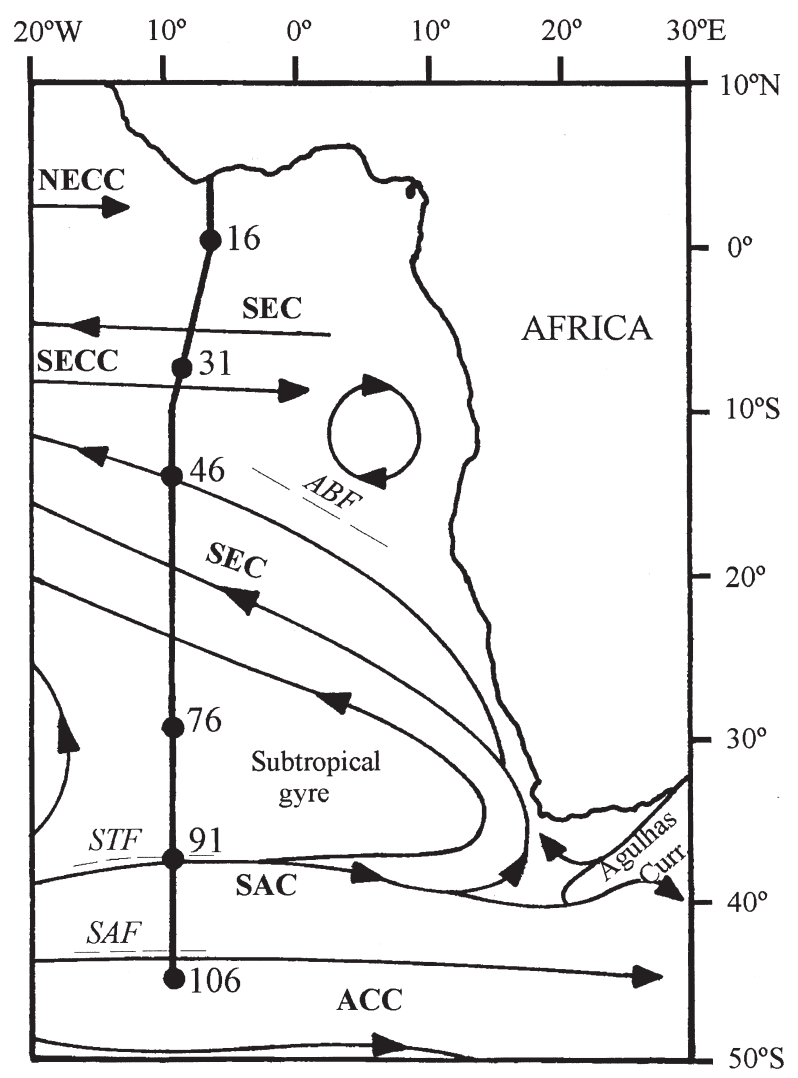

FIG. 1. - Map of the eastern South Atlantic Ocean showing the six TOC sampling sites along A14. Major features of the climatologically driven upper ocean circulation are also shown (adapted from Peterson and Stramma, 1991). NECC, North Equatorial Counter Current SEC, South Equatorial Current; SECC, South Equatorial Counter Current; SAC, South Atlantic Current; ACC, Antarctic Circumpolar Current; $A B F$, Angola-Benguela Front; STF, Subtropical Front; $S A F$, Subantarctic Front.

\section{MATERIAL AND METHODS}

\section{Sampling programme}

During Leg 1 of cruise CITHER-3 (R/V l'Atalante, January 13 to February 16, 1995), the meridional WOCE line A14 was occupied east of the Mid- 
dle Atlantic Ridge, from $4^{\circ} \mathrm{N}$ to $45^{\circ} \mathrm{S}$ (Fig. 1). Conductivity-temperature-depth (CTD) data were calibrated and dissolved oxygen and nitrate were collected and determined following standard procedures (Le Groupe CITHER-3, 1998).

Seawater samples for total organic carbon (TOC) analysis were collected at 10 selected depths at 6 stations spaced $\sim 800 \mathrm{~km}$ apart. Samples were directly drawn from the 10 litre Niskin bottles into $100 \mathrm{ml}$ acid-washed glass containers, after rinsing three times. They were subsequently acidified to $\mathrm{pH} \sim 2$ with $\mathrm{H}_{2} \mathrm{SO}_{4}$, covered with a Teflon top, and stored in the dark until analysis in the laboratory. Chen and Wangersky (1996) showed that acidification and dark cold storage is a convenient and practical method for DOC preservation, although it will not completely prevent the slow oxidation of labile materials. In this sense, Sharp et al. (1995) demonstrated that quick freezing and freezer storage in Teflon-sealed vials is very suitable for deep ocean sample preservation. Low particulate organic carbon (POC) levels in open ocean waters $(<5 \%$ of TOC) prevented us from filtering the samples (Carlson and Ducklow, 1995; Peltzer and Hayward, 1996).

\section{The analytical system}

TOC samples were analysed in the base laboratory by high temperature catalytic oxidation (HTCO), with a commercial Shimadzu TOC-5000. The acidified samples were decarbonated by vigorous stirring with high purity air for $\sim 20 \mathrm{~min}$, and injected onto a pre-conditioned $0.5 \% \mathrm{Al}_{2} \mathrm{O}_{3}$ catalyst at $680^{\circ} \mathrm{C}$, under an atmosphere of high purity air. The combustion products $\left(\mathrm{CO}_{2}, \mathrm{H}_{2} \mathrm{O}\right.$, etc. $)$ subsequently passed through: 1) a solution of $25 \% \mathrm{H}_{3} \mathrm{PO}_{4}$; 2) an electronic dehumidifier; and 3) a halogen scrubber. Quantitatively produced $\mathrm{CO}_{2}$ gas was measured with a Non-Dispersive Infra-Red (NDIR) detector and the resulting area was estimated with an in-built peak integrator. Catalyst conditioning consisted of washing the catalyst with a large volume of UV irradiated MilliQ water (Copin-Montégut and Avril, 1993).

Potassium Hydrogen Phthalate (KHP) was used for calibrating the system. A 4-point calibration curve prepared in UV-MilliQ water was performed every day. The correlation coefficient $\left(r^{2}\right)$ for the individual calibration curves was $>0.9997$. A single regression line was used for the whole set of calibrations, the coefficient of variation $(\mathrm{CV})$ of the slope being $0.6 \%$ and $r^{2}=0.9994$. The 'system blank' (= 'instrument blank' + TOC in UV-MilliQ water) was low and stable, equivalent to $10.3 \pm 0.4$

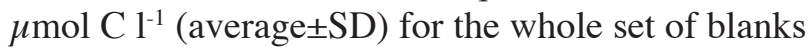
analysed (one every ten samples). UV-MilliQ water has near-zero DOC and is suitable for blank correction (Sharp et al., 1995; Peltzer et al., 1996). TOC concentrations were calculated by dividing the average area of the 3-5 replicate injections of $200 \mu \mathrm{l}$ by the slope of the average regression line and subtracting the average 'system blank'. The average CV of the peak area was $\sim 1 \%$, i.e. equivalent to \pm 0.8 $\mu \mathrm{mol} \mathrm{C} \mathrm{^{-1 }}$. In addition, 2 replicate analyses of inorganic carbon (optional in the Shimadzu TOC 5000) were performed to check for complete decarbonation. Just after analysing the CITHER-3 samples, we ran the set of 14 samples distributed as part of the '2nd stage of the large community methods comparison of DOC' by Prof. J.H. Sharp (Univ. of Delaware), who reported that our results were within the permitted $\pm 10 \%$ limits (J.H. Sharp, personal communication). In December 1996, Prof. J.H. Sharp distributed BLANK and DEEP OCEAN reference materials among the DOC analysts. We tested the accuracy of our DOC measurements with these reference materials daily in 1997-98, with very satisfactory results. Using essentially the same method as with the CITHER-3 samples, we obtained an average concentration of $45.8 \pm 1.1 \mu \mathrm{M}-\mathrm{C}(\mathrm{n}=40)$ for the DEEP OCEAN reference (Sargasso Sea deep water, $2600 \mathrm{~m})$ and $0.4 \pm 07 \mu \mathrm{M}-\mathrm{C}(\mathrm{n}=43)$ for the BLANK reference material. The nominal values provided by the reference laboratories are $44.0 \pm 1.5$ and $0.0 \pm 1.5 \mu \mathrm{M}-\mathrm{C}$ respectively.

\section{RESULTS AND DISCUSSION}

\section{Water mass variability}

The full-depth $\theta-S$ diagrams for the selected stations (Le Groupe CITHER-3, 1998) clearly show contrasting water masses along line A14 (Fig. 2). Stns $16\left(0^{\circ} \mathrm{S}\right), 31\left(8^{\circ} \mathrm{S}\right)$ and $46\left(15^{\circ} \mathrm{S}\right)$ are characterised by higher salinity for a given temperature within the thermocline, which is distinctive of South Atlantic Central Water (SACW) in the eastern South Atlantic north of the SEC (Gordon and Bosley, 1991). On the other hand, stn $76\left(30^{\circ} \mathrm{S}\right)$ is in the eastern limb of the Subtropical gyre, stn $91\left(38^{\circ} \mathrm{S}\right)$ is within the Subtropical Front (STF) and stn 106 $\left(45^{\circ} \mathrm{S}\right)$ is at the northern end of the Subantarctic Front (SAF), as can be drawn from the $\theta-S$ charac- 


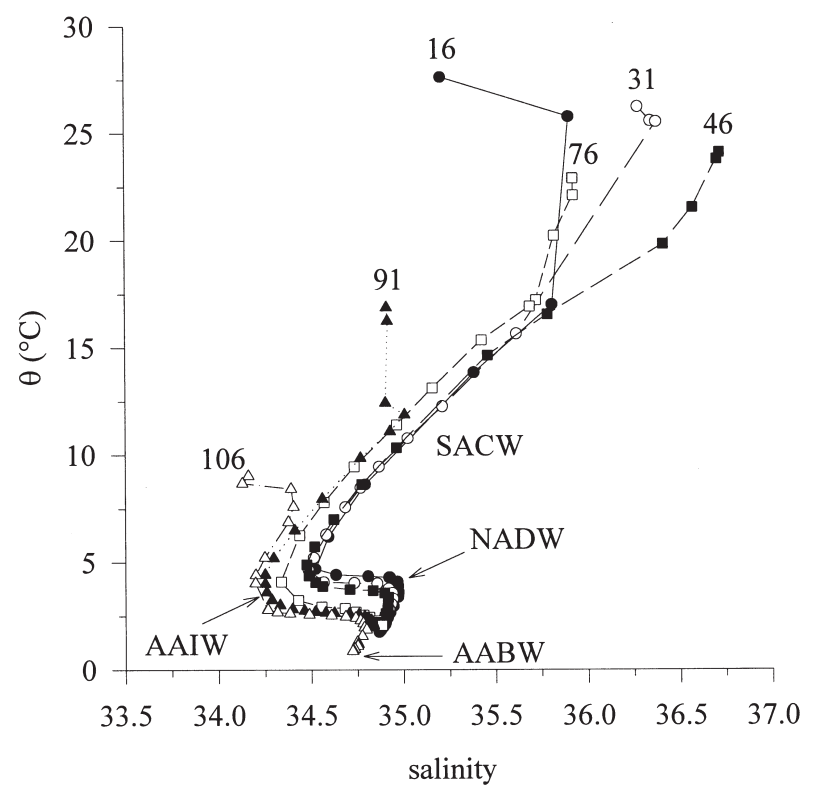

FIG. 2. - Composite full-depth $\theta-S$ diagrams for the six TOC sampling sites along A14. Circulation and mixing of major water masses in the eastern South Atlantic are characterised by their contrasting thermohaline properties. SACW, South Atlantic Central Water; AAIW, Antarctic Intermediate Water; NADW, North Atlantic Deep Water; AABW, Antarctic Bottom Water.

$$
\mathrm{NO}_{3}^{-}\left(\mu \mathrm{mol} \cdot \mathrm{kg}^{-1}\right)
$$

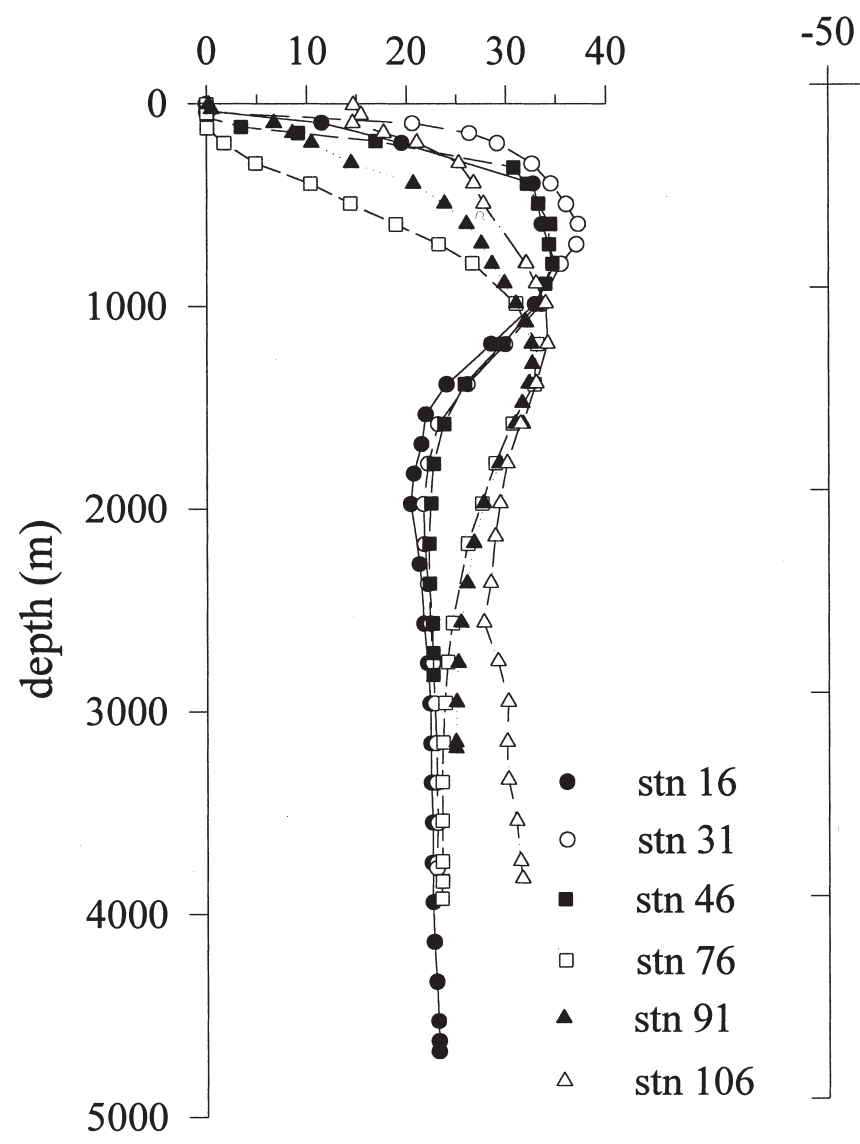

teristics of the upper layer (Peterson and Stramma, 1991). Clear zonation within the intermediate, deep and bottom waters is also observed: the purest fractions of the low-salinity AAIW and AABW occur south of the SEC. On the other hand, the high-salinity NADW appears strongly diluted compared with the core of this water mass north of the SEC (Reid, 1989; Gordon and Bosley, 1991).

\section{Dissolved oxygen and nutrient salt distributions}

Full-depth nitrate and apparent oxygen utilisation (AOU) profiles for the selected stations (Fig. 3a and b) illustrate the contrasting contribution of advection and organic matter oxidation along the $5500 \mathrm{~km}$-long line A14. Stations south of the $\operatorname{SEC}(76,91,106)$ are characterised by maximum AOU $\left(>135 \mu \mathrm{mol} \mathrm{kg}^{-1}\right)$ and nitrate levels at $\sim 1500 \mathrm{~m}$ depth, associated with the northward penetration of the upper Circumpolar Deep Water (UCDW), advected from the eastwardflowing Antarctic Circumpolar Current (Reid, 1989). The presence of the nutrient-rich purest fractions of

$$
\text { AOU }\left(\mu \mathrm{mol} \cdot \mathrm{kg}^{-1}\right)
$$

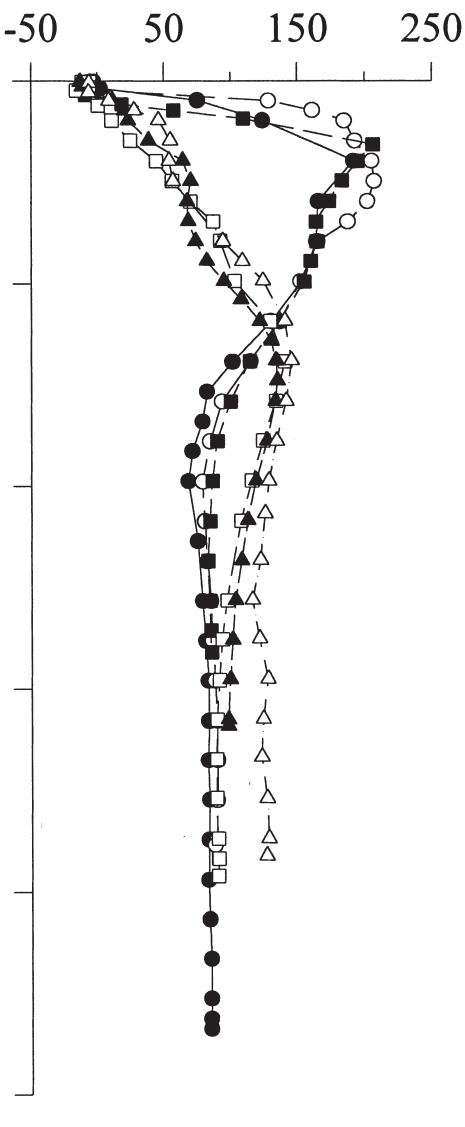

FIG. 3. - Composite full-depth profiles of nitrate and apparent oxygen utilisation (AOU) for the six stations sampled along A14. 
AABW is observed below $2500 \mathrm{~m}$ at stn 106. A clear poleward increase in nitrate occurs in thermocline waters. North of the SEC (stns 16, 31, 46), the most striking feature is the AOU maximum $(>190 \mu \mathrm{mol}$ $\mathrm{kg}^{-1}$ ) at $\sim 200-400 \mathrm{~m}$ (Gordon and Bosley, 1991). According to Reid (1989), the cyclonic field centred at $10-15^{\circ} \mathrm{S}$, together with the Ekman divergence and upwelling providing nutrients to the euphotic zone and the associated fallout of oxidizable organic matter into the subsurface waters trapped in the flow, must be the reasons for the massive local oxygen consumption that is observed. The multiple linear regression with $\theta$ and $\mathrm{AOU}$ for all samples where organic matter oxidation is dominant (i.e. AOU $>0$ ) in the upper $1000 \mathrm{~m}$ explains $97 \%$ of the observed variance in the nitrate distribution (Eq. 1). The simple regression with temperature only retains $65 \%$ of the variance.

$$
\begin{aligned}
& \mathrm{NO}_{3}=24.9-1.31 \cdot \theta+0.099 \mathrm{AOU} \\
& r^{2}=0.97 \quad n=65 \quad p<0.001
\end{aligned}
$$

The AOU coefficient coincides with the expected value of the stoichiometric ratio $1 / R_{\mathrm{N}}=-\Delta \mathrm{NO}_{3}{ }^{-}$ $/ \Delta \mathrm{O}_{2} \sim 0.10$ from the literature (Broecker, 1974; Anderson and Sarmiento, 1994), indicating that: 1) $\theta$ removes the effect of water mass mixing on the nitrate and AOU distributions in the upper $1000 \mathrm{~m}$; and 2) AOU in subsurface waters is related to the oxidation of phytogenic organic nitrogen to nitrate at the basin-scale of the eastern South Atlantic. This result confirms Broeker's (1974) observation of a linear relationship between the conservative tracer 'NO' $\left(=\mathrm{O}_{2}+R_{\mathrm{N}} \cdot \mathrm{NO}_{3}^{-}\right)$and $\theta$.

\section{TOC in deep waters}

Despite the complex advection and mixing patterns of waters of southern (AAIW, CDW and AABW) and northern (NADW) origins (Fig. 2) with extremely different degrees of ventilation along A14 (Fig. 3) - TOC levels below $500 \mathrm{~m}$ are quasi-

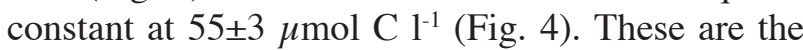
only TOC values reported for the remote Eastern South Atlantic to date. Following the recent study by Hansell and Carlson (1998) on TOC levels in deep waters of the World Ocean, we should expect a concentration of 44-45 $\mu \mathrm{mol} \mathrm{C} \mathrm{^{-1 }}$ in the deep South Atlantic. This is the concentration that they obtained in the Western North Atlantic. Other reported concentrations in the deep North Atlantic are $50 \mu \mathrm{mol} \mathrm{C}$ $1^{-1}$ in the Gulf of Mexico (Guo et al., 1994), 50-55

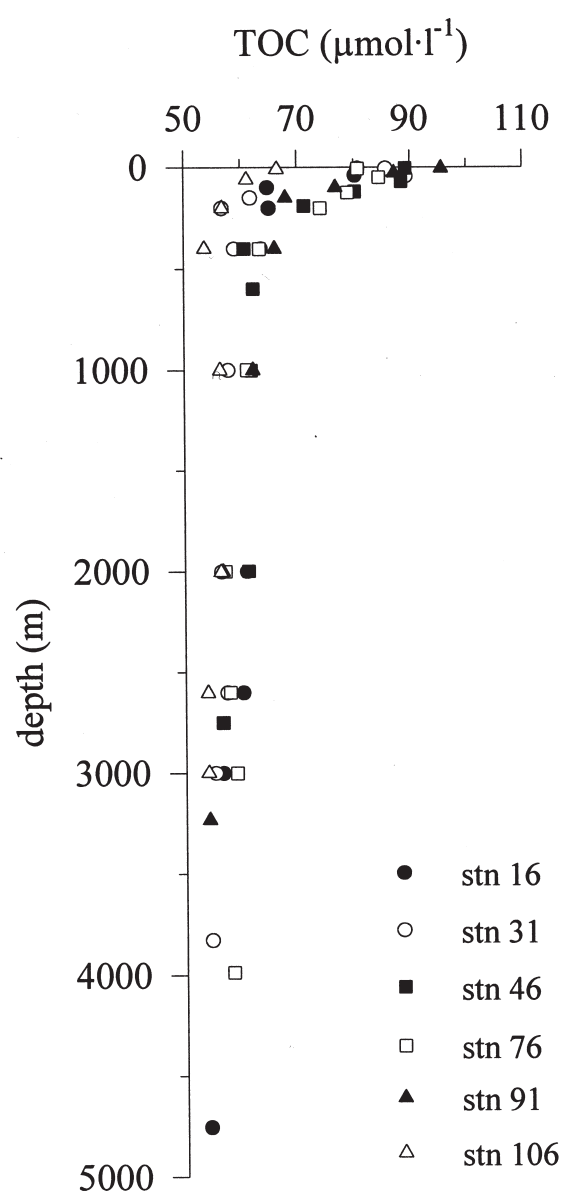

FIG. 4. - Full-depth total organic carbon (TOC) profiles for the six stations sampled along A14.

$\mu$ mol C $1^{-1}$ in Georges Bank (Chen et al., 1996), $50 \pm 3 \mu \mathrm{mol} \mathrm{C} \mathrm{^{-1 }}$ near Bermuda (Pakulsky and Benner, 1994), $51 \pm 4 \mu \mathrm{mol} \mathrm{C} ~^{-1}$ in the Bay of Biscay (X.A. Alvarez-Salgado and A.E.J.M. Miller, unpubl.) and $46 \pm 7 \mu \mathrm{mol} \mathrm{C} \mathrm{l}^{-1}$ in the Equatorial Atlantic (Thomas et al., 1995). Therefore, our values are at the top end of previous studies and could even exceed the permitted $\pm 10 \%$ limits. However, we do not find any strong reason for rejecting the data. Major evidences have been presented in the Material and Methods section on the accuracy of our instrument against an international reference for analytical quality. It should be highlighted that the critical 'system blank' correction produces values of the BLANK reference material that are not statistically different from zero. Contamination during storage seems unlikely considering the consistency of the profiles in Figs. 4 and 5. We avoided exposure of the samples to any source of volatile organic contamination during storage, which could affect all samples uniformly. However, we also have no argu- 

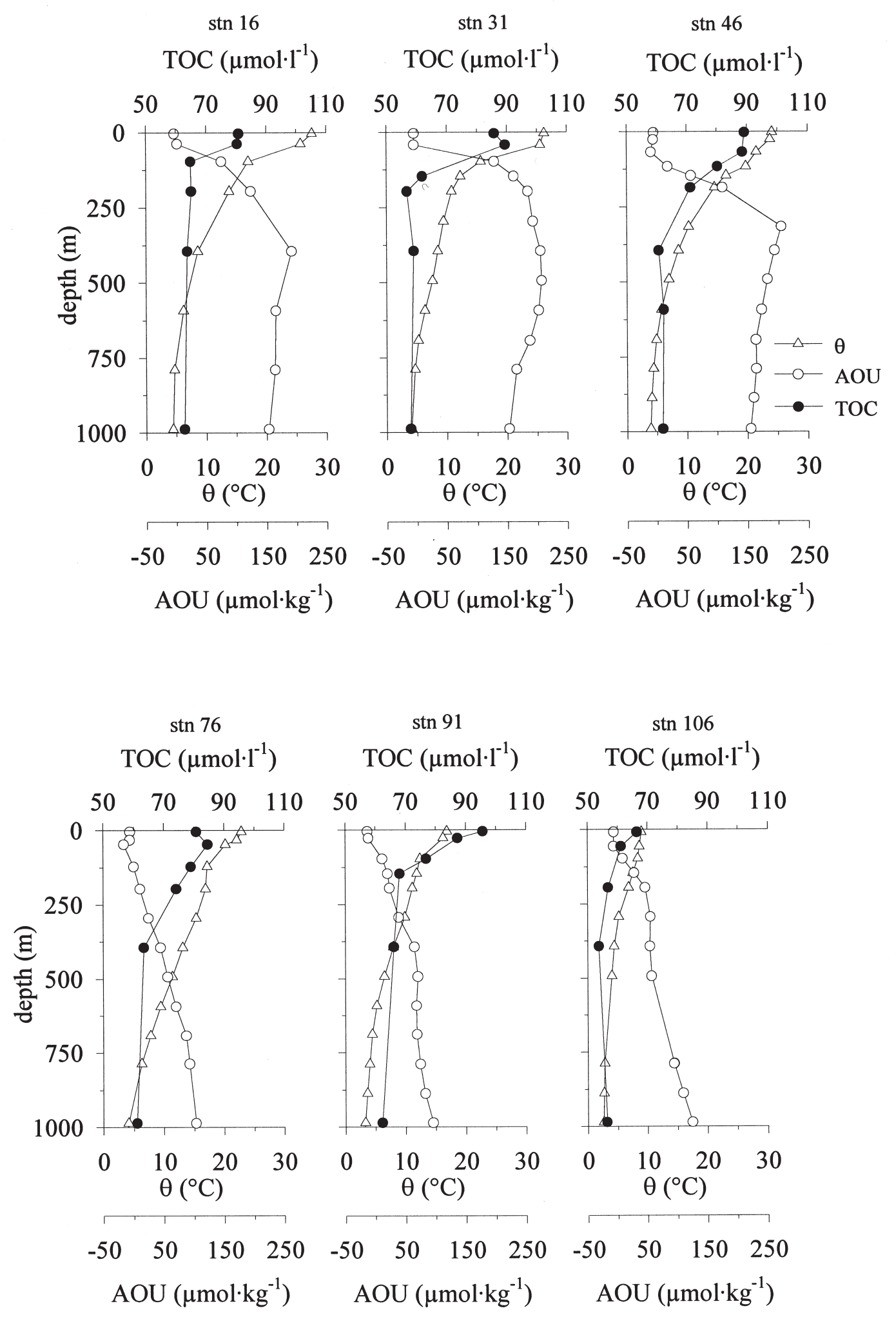

FIG. 5. - Potential temperature ( $\theta$ ), apparent oxygen utilisation (AOU) and total organic carbon (TOC) profiles in the upper $1000 \mathrm{~m}$ for the six stations where TOC was sampled along A14.

ments to explain a TOC excess in deep waters of the eastern South Atlantic. In any case, the study of the significance of physical and biological processes on
TOC distributions in thermocline waters presented below is not dependent on the accuracy of TOC concentrations in the deep ocean. 


\section{TOC in thermocline waters}

An excess of non-degraded TOC compared to the refractory deep-water baseline is observed in surface waters of the Equatorial (stn 16), Subequatorial (stns 31 and 46) and Subtropical (stns 76 and 91) regions (Fig. 5). Average TOC in the upper $100 \mathrm{~m}$ is 76 $\mu \mathrm{mol} \mathrm{C} \mathrm{^{-1 }}$ (excess of $25 \mathrm{~g} \mathrm{C} \mathrm{m}^{-2}$ ) at stn 16 and 82-87 $\mu \mathrm{mol} \mathrm{C} \mathrm{^{-1 }}$ (excess of 32 to $38 \mathrm{~g} \mathrm{C} \mathrm{m}^{-2}$ ) at stns 31-91, which are within the expected DOC excess ranges in marine systems world-wide (see review by Thingstad et al., 1997). The observed accumulation of phytogenic carbon represents a considerable fraction of the annual primary production in these remote areas. According to Berger and Herguera's (1992) synthetic map, annual productivity integrated over the surface $100 \mathrm{~m}$ must be $\sim 60-90 \mathrm{~g} \mathrm{C} \mathrm{m}^{-2} \mathrm{y}^{-1}$ at stns 16 and 31, 40-60 $\mathrm{g} \mathrm{C} \mathrm{m}^{-2} \mathrm{y}^{-1}$ at stns 46 and 91 and $\sim 25-30 \mathrm{~g} \mathrm{C} \mathrm{m}^{-2} \mathrm{y}^{-1}$ at stn 76 . These numbers indicate that the observed TOC excess could represent from $25-40 \%$ of the annual primary productivity in the eastern Equatorial Atlantic to as much as $100 \%$ in the oligotrophic Subtropical gyre. These percentages are only for reference, as we do not know about the net formation rates of the TOC excess or even how much of the actual excess has been advected to the study sites, but they indicate that the pool of non-degraded TOC seems to be a key transient sink for the phytogenic carbon all along the temperate eastern South Atlantic. By contrast, at the SAF (stn 106; surface $\theta$ and nitrate, $9^{\circ} \mathrm{C}$ and $15 \mu \mathrm{mol} \mathrm{kg}^{-1}$ respectively), the average TOC falls dramatically to $62 \mu \mathrm{mol} \mathrm{C} \mathrm{^{-1 }}$ (excess of only $\left.9 \mathrm{~g} \mathrm{C} \mathrm{m}^{-2}\right)$.

TOC profiles in the upper $1000 \mathrm{~m}$ are essentially parallel to temperature at all the study sites along A14 (Fig. 5). Temperature, an index of water mass mixing, retains $>80 \%$ of the variance observed in the individual TOC profiles $(n=6-7, p<0.001)$, except at stn 106, where the direct correlation was lower $\left(r^{2}=0.63, \mathrm{n}=5, p<0.001\right)$ because of the limited ranges of both variables $\left(2.6-9.0^{\circ} \mathrm{C}, 67-54\right.$

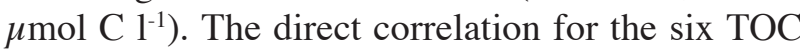
profiles collectively was $r^{2}=0.70(\mathrm{n}=36, p<0.001)$, indicating the dominance of mixing of accumulated TOC produced in the warm upper waters with refractory TOC in cold deep waters (Carlson et al., 1994; Guo et al., 1995; Hansell and Waterhouse, 1997). However, TOC seems to be lower than expected by mixing in the very aged subsurface waters of the Equatorial and Subequatorial South Atlantic (stns 16, 31 and 46), where a maximum apparent oxygen utilisation (AOU) of $>190 \mu \mathrm{mol}$ $\mathrm{kg}^{-1}$ at $\sim 200-400 \mathrm{~m}$ is perceived (Fig. 3). TOC and AOU exhibit a good correlation $\left(r^{2}>0.75\right)$ for all the individual profiles $(\mathrm{n}=6-7, p<0.001)$, except for stn $106\left(r^{2}=0.49, \mathrm{n}=5, p=0.19\right)$. The correlation for the whole dataset in the upper $1000 \mathrm{~m}$, excluding the southernmost station, is:

$$
\begin{gathered}
\text { TOC }=81-0.13 \text { AOU } \\
r^{2}=0.76 \quad n=31 \quad p<0.001
\end{gathered}
$$

This indicates a clear relationship between the two variables, either at the local or the basin scales, with a slope $(-\Delta \mathrm{TOC} / \Delta \mathrm{AOU}$ ratio) of $0.13 \pm 0.01 \mathrm{~mol}$ $\mathrm{C}$ mol O${ }_{2}^{-1}$. Recent reliable DOC data have revealed some degree of covariance between DOC (or TOC) and AOU in the upper few hundred meters of the ocean (Kepkay and Wells, 1992; Guo et al., 1994; Thomas et al., 1995; Peltzer and Hayward, 1996), as previously suggested by Ogura (1970). These authors obtained slopes of $<0.25 \mathrm{~mol} \mathrm{C} \mathrm{mol} \mathrm{O}_{2}^{-1}$, instead of the $0.72 \mathrm{~mol} \mathrm{C} \mathrm{mol} \mathrm{O}_{2}^{-1}$ expected from the Redfield stoichiometry $\left(\mathrm{O}_{2}: \mathrm{C}: \mathrm{N}: \mathrm{P}=148: 106: 16: 1\right.$; Anderson, 1995). If a direct cause-and-effect relationship between DOC and AOU occurred, DOC would contribute $<35 \%$ to the observed bulk oxygen consumption. However, most of these authors also suggested that the correlations could be partly due to the dependence of both DOC and AOU on water mass mixing, as proposed by Menzel and Ryther (1968). The observed correlation of temperature with TOC $\left(r^{2}=0.76, \mathrm{n}=31, p<0.001\right)$ and AOU $\left(r^{2}=\right.$ $0.51, \mathrm{n}=67, p<0.001$ ) for the upper $1000 \mathrm{~m}$ in our limited database makes it necessary to consider the effect of mixing. As previously demonstrated, temperature is a suitable tracer for correcting the effect of water mass mixing in the upper $1000 \mathrm{~m}$ of the eastern South Atlantic. Therefore, the multiple correlation of TOC with temperature and AOU will give a $-\Delta \mathrm{TOC} / \triangle \mathrm{AOU}$ ratio independent of water mass mixing. The corresponding linear equation (excluding stn 106) is:

$$
\begin{aligned}
& \mathrm{TOC}=70+0.6 \theta-0.09 \text { AOU } \\
& r^{2}=0.81 \quad \mathrm{n}=31 \quad p<0.005
\end{aligned}
$$

Consequently, TOC oxidation is linked to oxygen consumption in the upper $1000 \mathrm{~m}$, although the $-\Delta \mathrm{TOC} / \Delta \mathrm{AOU}=0.09 \pm 0.02$ only represents $\sim 13 \%$ of the Redfield demand. A comparison of Eqs (2) and (3) indicates that water mass mixing tends to overestimate the contribution of DOC to 
AOU in the eastern South Atlantic. Therefore, rather than from TOC (suspended+dissolved organic carbon), it is logical to suggest that oxygen consumption in subsurface thermocline waters of the study sites is mainly from large organic particles not accounted for in TOC analyses, such as sinking aggregated detritus. The $-\Delta \mathrm{NO}_{3}{ }^{-} / \Delta \mathrm{O}_{2}$ ratio of $\sim 0.10$ obtained from Eq. (1) agrees with the mineralisation at depth of fresh organic matter of Redfield composition (C/N ratio of 6.6; Anderson, $1995)$ exported from surface ocean waters. Detritus, which partially originates from DOM aggregation, has much higher $\mathrm{C} / \mathrm{N}$ ratios (Verity et al., 1996, 2000). Therefore, if these sinking semi-labile materials make a major contribution to oxygen consumption in the upper $1000 \mathrm{~m}$, nitrogen mineralisation rates should exceed carbon mineralisation rates to eventually produce the observed Redfield mineralisation ratio. Alternatively, Anderson and Sarmiento (1994) have suggested that the flux of organic matter to the deep ocean could be dominated by fast-sinking labile organic matter of Redfield composition produced by sporadic highly productive events, which escapes the degradation in the upper ocean. Accurate measurements of mineralisation processes in deep waters are necessary to elucidate this apparent disagreement between the composition of exported materials and the resulting inorganic carbon and nutrient distributions.

In areas where deep winter convection is prevented (stns 16 to 91 ), turbulent diffusion is the mechanism for the downward transport of TOC. The turbulent diffusion flux of TOC from the stratified upper $100 \mathrm{~m}$ to the subsurface waters in the $100-400 \mathrm{~m}$ depth range can be roughly estimated from $F=-K_{Z} \cdot \triangle T O C / \triangle Z$ (Copin-Montégut and Avril, 1993; Guo et al., 1994). $K_{\mathrm{Z}}$ is the turbulent diffusion coefficient, which can be calculated by means of the equation $K_{Z}=\varepsilon^{\cdot} N^{-2} \cdot R /(1-R)$. The dissipation rate $(\varepsilon)$ and the Richardson number $(R)$ have been set to constant values of $10^{-8} \mathrm{~m}^{2} \mathrm{~s}^{-3}$ and 0.2 respectively, following Copin-Montégut and Avril (1993). Consequently, $K_{\mathrm{Z}}$ variability depends on the square of the Brunt-Väisälä frequency, $N^{2}=$ $(g / \rho) \cdot(\mathrm{d} \rho / \mathrm{d} Z)$. Values of $N^{2}$ averaged over the upper $400 \mathrm{~m}$ increased monotonically from $1.9 \mathrm{~m}^{2} \mathrm{~d}^{-1}$ at stn 16 to $5.5 \mathrm{~m}^{2} \mathrm{~d}^{-1}$ at stn $91 . \triangle T O C / \triangle Z$ is calculated as $-\left(T O C_{0-100}-T O C_{100-400}\right) /(250-50)$ and varied from 0.7 to $1.5 \mathrm{mgC} \mathrm{m}^{-4}$. Finally, the resulting turbulent diffusion fluxes ranged from $1.3 \mathrm{mg} \mathrm{C} \mathrm{m}^{-2} \mathrm{~d}^{-}$ ${ }^{1}$ at stn 16 to $5.3 \mathrm{mg} \mathrm{C} \mathrm{m}^{-2} \mathrm{~d}^{-1}$ at 76 in the STF, where the combination of a large TOC gradient with moderate stratification yields the highest flux. These numbers are extremely low when compared with the average DOC excess observed in the upper $100 \mathrm{~m}$, which 1) confirms that stability controls the accumulation of TOC in the upper layer (Hansell and Waterhouse, 1997); 2) indicates that turbulent diffusion is not an important route of injection of phytogenic DOC in subsurface thermocline waters; and 3) supports the hypothesis of a minor contribution of TOC to the local oxygen consumption, as inferred from Eq (3).

At the SAF ( $\operatorname{stn} 106)$, the observed TOC excess at the time of sampling (mid February, the austral summer) was the lowest all along line A14. This could be simply due to low stability $\left(K_{\mathrm{z}}>10 \mathrm{~m}^{2} \mathrm{~d}^{-1}\right)$ and/or low production rates of DOC. Conversely, it could be related to the large nitrate and phosphate concentrations in the upper $100 \mathrm{~m}\left(15 \mu \mathrm{mol}-\mathrm{N} \mathrm{l}^{-1}\right.$ and $1 \mu \mathrm{mol}-\mathrm{P}^{-1}$; Fig. 3), which favours bacterial degradation of DOC, in contrast with nutrient-limited ecosystems, where competition with phytoplankton for nutrient salts can dramatically reduce the degradation of C-rich DOM (Williams, 1995; Thingstad et al., 1997). Nitrate levels in the upper $100 \mathrm{~m}$ are $0.0-0.5 \mu \mathrm{M}-\mathrm{N}$ in the DOC-rich waters of the Equatorial, Subequatorial and Subtropical eastern South Atlantic.

The build up of DOC in surface waters seems to develop from a fairly intricate assortment of biological and photochemical processes. The combination of an excess production of C-rich DOM such as mono- and polysaccharides (Kirchman et al., 1991; Benner et al., 1992; Pakulski and Benner, 1994), and low bacterial activity in nutrientlimited ecosystems (Williams, 1995; Thingstad et $a l ., 1997)$ could greatly contribute to the observed DOC accumulation. This conjecture is supported by the multiple correlation of TOC with temperature and AOU for samples where $\mathrm{AOU}<0 \quad\left(r^{2}=\right.$ $0.64, \mathrm{n}=13$ ). The $-\Delta \mathrm{TOC} / \Delta \mathrm{AOU}$ ratio (independent of temperature) is $1.0 \pm 0.4 \mathrm{~mol} \mathrm{C} \mathrm{mol} \mathrm{O}{ }_{2}^{-1}(p<$ 0.01 , a value compatible with the net production of carbohydrates in the euphotic layer. This number must be taken with care: the slope could be overestimated because loss to the atmosphere of the excess oxygen produced has not been considered. Other processes contributing to the accumulation of phytogenic DOM in surface ocean waters could also be phototransformation to biorefractory materials (Benner and Biddanda, 1998; Obernosterer et al., 1999) or photochemical inhibition of bacterial growth (Herndl et al., 1993). 


\section{ACKNOWLEDGEMENTS}

We are very grateful to the captain and the crew of $R / V$ L'Atalante for their help during the cruise. We also thank the co-ordinators of the French programme 'Circulation thermohaline' (CITHER), who invited us to joint 'Le Groupe CITHER-3'. CTD and dissolved oxygen data were kindly provided by IFREMER-Brest. R. Penín helped us drawing figures. Comments by J.H. Sharp and an anonymous reviewer helped to improve the manuscript. Financial support for this work came from the Spanish 'Comisión Interministerial de Ciencia y Tecnología (CICYT)', contract No. ANT94-1168-E, and from the 'Institut Français de Recherche pour l'exploitation de la Mer (IFREMER)', contract No 941430 087. A fellowship from the EC MAS2 project CT93-0065 allowed M.D. Doval to carry out this work. X.A.A.-S. was partially funded by a 'Contrato de Incorporación' of the Spanish 'Ministerio de Educación y Ciencia'.

\section{REFERENCES}

Anderson, L.A. - 1995. On the hydrogen and oxygen content of marine phytoplankton. Deep-Sea Res. I, 42: 1675-1680.

Anderson, L.A. and J.L. Sarmiento. - 1994. Redfield ratios of mineralization determined by nutrient data analysis. Global Biogeoche. Cycles, 8: 65-80.

Azam, F., T. Fenchel, J.G. Field, J.S. Gray, L.A. Meyer-Reil and F. Thingstad. - 1983. The ecological role of water column microbes in the sea. Mar. Ecol. Progr. Ser., 10: 257-273.

Bascatow, R. and E. Maier-Reimer. - 1991. Dissolved organic carbon in modelling oceanic new production. Global Biogeochem. Cycles, 5: 71-85.

Bauer, J.E., P.M. Williams and E.R.M. Druffel. - 1992. ${ }^{14}$ C activity of dissolved organic carbon fractions in the north central Pacific and Sargasso Sea. Nature, 357: 667-670.

Benner, R., J.D. Pakulski, M. McCarthy, J.I. Hedges and P.G. Hatcher. - 1992. Bulk chemical characteristic of dissolved organic matter in the ocean. Science, 255: 1561-1564

Benner, R. and B. Biddanda. - 1998. Photochemical transformations of surface and deep marine dissolved organic matter: effects of bacterial growth. Limnol. Oceanogr., 43: 1373-1378.

Berger, W.H. and J.C. Herguera. - 1992. Reading the sedimentary record of the ocean's productivity. In: P.G. Falkowski and A.D. Woodhead (eds.), Primary Production and Biogeochemical Cycles in the Sea. Environmental Science Research, Vol. 43, pp. 455-486, Plenum, New York.

Broecker, W.S. - 1974. "NO" a conservative water-mass tracer. Earth and Planetary Science Letters, 23: 100-107.

Bronk, D.A., P.M. Glibert and B.B. Ward. - 1994. Nitrogen uptake, dissolved organic nitrogen release, and new production. Science, 265: 1843-1846.

Carlson, C.A., H.W. Ducklow and A.F. Michaels. - 1994. Annual flux of dissolved organic carbon from the euphotic zone in the North-western Sargasso Sea. Nature, 371: 405-408.

Carlson, C.A. and H.W. Ducklow. - 1995. Dissolved organic carbon in the upper ocean of the central equatorial Pacific Ocean, 1992: Daily and finescale vertical variations. Deep Sea Res. II, 42: 639-656.

Chen, R.F., B. Fry, C.S. Hopkinson, D.J. Repeta and E.T. Peltzer. 1996. Dissolved organic carbon on Georges Bank. Cont. Shelf Res., 16: 409-420.

Chen, W. and P.J. Wangersky. - 1996. Rates of microbial degrada- tion of dissolved organic carbon from phytoplankton cultures. J. Plankton Res., 18: 521-1533.

Copin-Montégut, G. and B. Avril. - 1993. Vertical distribution and temporal variation of dissolved organic carbon in the North Western Mediterranean Sea. Deep Sea Res. I, 40: 1963-1972.

Doval, M.D. and D.A. Hansell. - 2000. Organic carbon and apparent oxygen utilization in the western South Pacific and the Central Indian Oceans. Mar. Chem., 68: 249-264.

Eppley, R.W. and B.J. Peterson. - 1979. Particulate organic matter flux and planktonic new production in the deep ocean. Nature, 282: 677-680.

Gordon, A.L. and K.T. Bosley. - 1991. Cyclonic gyre in the tropical South Atlantic. Deep-Sea Res., 38 (Suppl. 1): S323-S343.

Guo, L., C.H.Jr. Coleman and P.H. Santschi. - 1994. The distribution of colloidal and dissolved organic carbon in the Gulf of Mexico. Mar. Chem., 45: 105-119.

Guo, L., P.H. Santschi and K.W. Warnken. - 1995. Dynamics of dissolved organic carbon (DOC) in oceanic environments. Limnol. Oceanogr., 40: 1392-103.

Hansell, D.A. and C.A. Carlson. - 1998. Deep-ocean gradients in the concentration of dissolved organic carbon. Nature, 359: 263-265.

Hansell, D.A. and T.Y. Waterhouse. - 1997. Control of the distributions of organic carbon and nitrogen in the eastern Pacific Ocean. Deep-Sea Res. I, 44: 843-857.

Herndl, G.J., G. Müller-Niklas and J. Frick. - 1993. Major role of UV-B in controlling bacterioplankton growth in the surface layer of the ocean. Nature, 361: 717-719.

Kepkay, P.E. and M.L. Wells. - 1992. Dissolved organic carbon in North Atlantic surface waters. Mar. Ecol. Progr. Ser., 80: 275-283.

Kirchman, D.L., Y. Suzuki, C. Gardise and H.W. Ducklow. - 1991. High turnover rates of dissolved organic carbon during a spring phytoplankton bloom. Nature, 352: 612-614.

Kirchman, D.L., C. Lancelot, M. Fasham, L. Legendre, G. Radach and M. Scott. - 1993. Dissolved organic material in biogeochemical models of the ocean. In: Evans, G.T and M.J.R. Fasham, (eds.), Towards a model of Ocean Biogeochemical Processes, Series I: Global Environmental Change, pp. 209225. Berlin.

Legendre, L. and J. Le Fèvre. - 1995. Microbial food webs and the export of biogenic carbon in the oceans. Aquat. Microbial Ecol., 9: 69-77.

Le Groupe Cither-3. - 1998. Recueil de données. Volume 3: Traceurs Géochimiques. Rapport Interne LPO (98-03).

Menzel, D.W. and J.H. Ryther. - 1968. Organic carbon and the oxygen minimum in the South Atlantic Ocean. Deep-Sea Res., 15: 327-337.

Obernosterer, I., B. Reitner and G.J. Herndl. - 1999. Contrasting effects of solar radiation on dissolved organic matter and its bioavailability to marine bacterioplankton. Limnol. Oceanogr., 44: 1645-1654.

Ogura, N. - 1970. The relationship between dissolved organic carbon and apparent oxygen utilization in the western North Pacific. Deep-Sea Res., 17: 221-231.

Pakulski, J.D. and R. Benner. - 1994. Abundance and distribution of carbohydrates in the ocean. Limnol. Oceanogr., 39: 930-940.

Peterson, R.G. and T. Whitworth III. - 1989. The Subantarctic and Polar fronts in relation to deep water masses through the southwestern Atlantic. J. Geophy. Res., 94: 10817-10838.

Peterson, R.G. and L. Stramma. - 1991. Upper-level circulation in the South Atlantic Ocean. Progr. Oceanogr., 26: 1-73.

Peltzer, E.T., B. Fry, P.H. Doering, J.H. MacKenna, B. Norrman and U.L. Zweifel. - 1996. A comparison of methods for the measurement of dissolved organic carbon in natural waters. Mar. Chem., 54: 85-96.

Peltzer, E.T. and N.A. Hayward. - 1996. Spatial and temporal variability of total organic carbon along $140^{\circ} \mathrm{W}$ in the equatorial Pacific Ocean in 1992. Deep-Sea Res. II, 43: 1155-1180.

Reid, J.L. - 1989. On the total geostrophic circulation of the South Atlantic Ocean: flow patterns, tracers and transports. Progr. Oceanogr., 23:149-244.

Sambrotto, R.N., G. Savidge, C. Robinson, P. Boyd, T. Takahashi, D.M. Karl, C. Langdon, D. Chipman, J. Marra and L. Codispoti. - 1993. Elevated consumption of carbon relative to nitrogen in the surface ocean. Nature, 363 (6426): 248-250.

Sharp, J.H., R. Benner, L. Bennett, C.A. Carlon, S.E. Fitzwater, E.T. Peltzer and L.M. Tupe. - 1995. Analyses of dissolved 
organic carbon in seawater: The JGOFS EqPac methods comparison. Mar. Chem., 48: 91-108.

Sugimura, Y. and Y. Suzuki. - 1988. A high-temperature catalytic oxidation method for the determination of non-volatile dissolved organic carbon in seawater by direct injection of a liquid sample. Mar. Chem., 24: 105-131.

Thomas, C., G. Cauwet and J.-F. Minster. - 1995. Dissolved organic carbon in the equatorial Atlantic Ocean. Mar. Chem., 49: 155-169.

Thingstand, T.F., A. Hagström and F. Rassoulzadegan. - 1997. Accumulation of degradable DOC in surface waters: Is it caused by a malfunctioning microbial loop?. Limnol. Oceanogr., 42: 398-404.

Toggweiler, J.R. - 1989. Is the downward dissolved organic matter (DOM) flux important in carbon transport? In: W.H. Berger, V.S. Smatecek and G. Wefer (eds.), Productivity of the Ocean:
Present and Past, pp.65-83. John Wiley, Chichester.

Verity, P.G., T.M. Beatty and S.C. Williams. -1996 . Visualization and quantification of plankton and detritus using digital confocal microscopy. Aquat. Microb. Ecol., 10: 55-67.

Verity, P.G., S.C. Williams and Y. Hong. - 2000. Formation, degradation, and mass: volume ratios of detritus derived from decaying phytoplankton. Mar. Ecol. Progr. Ser., 207: 53-68.

Williams, P.J. leB. - 1995. Evidence for the seasonal accumulation of carbon-rich dissolved organic material, its scale in comparison with changes in particulate material and the consequential effect on net C/N assimilation ratios. Mar. Chem., 51: 17-29.

Williams, P.M. and E.R. Druffell. - 1987. Radiocarbon in dissolved organic matter in the central North Pacific Ocean. Nature, 330: 246-248.

Scient. ed.: P.J. Wangersky 